\title{
A theology of sin related to poverty
}

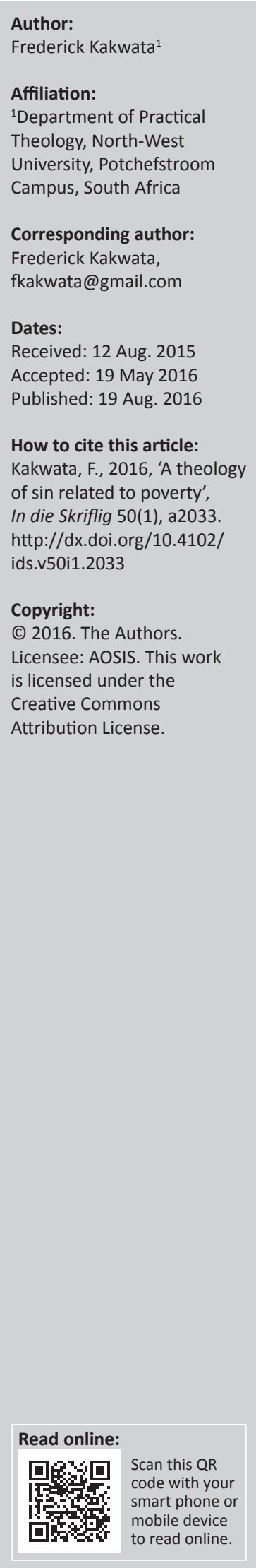

This article is a literature study and seeks to explore the correlation between sin and poverty. It is an important subject since it helps researchers and policy makers to understand what lies at the root of the persisting cycle of poverty within contemporary society globally, and particularly in Africa. The point of departure for this investigation is based on Myers' (2007:88) assumption: 'without a strong theology of $\sin$, comprehensive explanations of poverty are hard to come by'. It is argued that sin entails the violation of God's standard of loving Him and caring for others, which applies at a personal as well as societal level. It will be demonstrated that poverty as a situation of dire needs or a lack of means for survival is caused mainly by oppression and economic exploitation. These conditions express dysfunctional relationships, which portrays the lack of love. The virtue of love is therefore a key factor that provides correctives for the relationship between sin and poverty.

\section{Introduction}

This study does not attempt to establish the origin of sin. From the biblical narrative in the book of Genesis it is already accepted that sin is universal and originates from the first people, Adam and Eve. Thus the focus of the article is rather to build on this presupposition and discuss a theology of sin in relation to the fundamental issue of poverty in the contemporary African society. The stimulating question reads: What is sin and how does it relate to poverty? In other words, which factors can explain the relationship between sin and poverty sufficiently?

Using a practical approach as opposed to a dogmatic one, it would firstly be necessary for a brief examination of a biblical theological perspective on the nature of sin and poverty. This will be followed by an overview of the reality of poverty in Africa before discussing the relational understanding of poverty. Finally the nature of the image of God in humans will be explored and its social implications analysed, which would further clarify the relationship between sin and poverty.

\section{Biblical terminology for sin and its implications}

To understand the nature of sin and how it relates to poverty it is first of all necessary to examine the terminology describing this phenomenon. The Bible uses a large array of diverse concepts to designate sin in terms of various nuances. As will become clear, these terms portray the 'multidimensional picture of humankind' (Bowden 2005:1114) as well as delineate human relationships. The different concepts the biblical testimony uses for sin in relation to poverty can be classified into two groups, namely terms that emphasise the character, and those focusing on the causes of $\sin$ (Erickson 2013:515). It should be mentioned that sin can manifest at a personal as well as social level, the latter often referred to as social sin or evil. The Bible records numerous examples of collective sin. For example in Amos 2:6-7 the Lord pronounces judgement on Israel in the following terms: 'For three transgressions of Israel and for four I will not revoke its punishment because they sell the righteous for money and the needy for a pair of sandals'. ${ }^{1}$ And according to Isaiah 1:16-20 God urges his rebellious people to wash themselves, cleanse them, and to remove the evil of their deeds from God's sight.

\section{Terms that emphasise the character of sin Missing the mark}

The word most commonly used in the Old Testament to designate sin is the Hebrew term (chātā'), which basically means 'to miss the right point or to deviate from the norm' (Grenz 2000:183). In its literal sense as it appears in certain passages of the Old Testament, the word was used to describe an incorrect action. For instance in Judges 20:16 the narrator explains the lefthanded Israelites who could sling a stone at a hair without missing. Theologically the word is

1.All quotations from the Bible are taken from the NASB (New American Standard Bible), except when stated otherwise. 
related to human sinfulness and carries the meaning of 'missing the mark, being at fault, failing to perform a duty or to meet the demand of the law, or to be lacking, fall short of expectations inherent in certain relationships' (Alexander \& Baker 2003:765). These actions can occur involuntary or purposefully, as elucidated in Leviticus 4:2 and Numbers 15:28. Grenz (2000:183) also specifies that the word אטฺָָ (chāta') generally alludes to a sin that is committed 'whether in thought, word, or deed'.

In the New Testament the Greek word translated as sin is

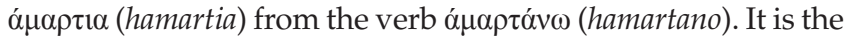
equivalent of the Hebrew word meaning as 'to miss the mark, to be in error, to sin, to be guilty of wrong' (Mounce 1993:64). From his interpretation Chan (2001:113) elaborates on the expression to miss the mark, as 'taking the wrong road, getting off the mark, and being substandard'. The main idea that both words,

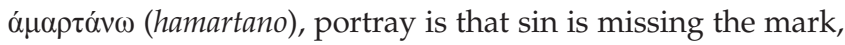
which implies to sin against God, fail to reach the character of God or to slip from the right way, or again, failing to meet the standard God has set of loving him wholeheartedly and loving others. As will be made clear later on this deficiency is not only due to tolerable errors. It is also a deliberate choice by refusing to meet the requirements of God's law.

\section{Ungodliness or lawlessness}

Ungodliness is another term used to designate sin particularly in the New Testament. The Greek word that expresses this

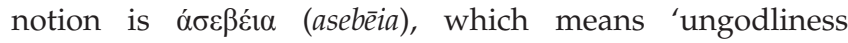
denoting a lifestyle devoid of any reverence towards God'

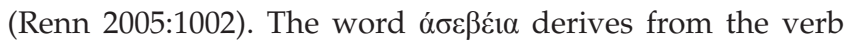

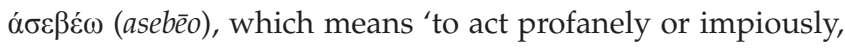
to $\sin$ against the gods' (Liddell \& Scott 2002:107). These words (ungodliness, impiety, profaneness) reveal that sin implies the lack of moral and spiritual qualities, and entail an act or thought that opposes the character of God. As 1 John 3:4 states clearly, 'Everyone who practices sin also practices lawlessness, and sin is lawlessness'.

\section{Transgression}

The Hebrew word interpreting the idea of transgression is עָבֵּר ('abar), which carries the sense of 'pass over, pass by, pass through' (Renn 2005:714). Renn makes it clear that the word עָּב ('abar) refers to a physical movement, for example crossing natural barriers such as a river or sea, traveling, or purposefully moving from one place to another. This word is used in several Old Testament passages to express the idea of 'transgressing a command or going beyond an established limit' (Erickson 2013:522). This is explained well in Numbers 14:41-42 when Moses asked the Israelites:

Why then are you transgressing the commandments of the Lord, when it will not succeed? Do not go up, or you will be struck down before your enemies, for the Lord is not amongst you.

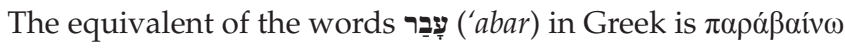
(parabainō), and derives from the word $\pi \alpha \rho \alpha \dot{\beta} \alpha \sigma i \varsigma$ (parabasis), which is an 'act of deviating from an established boundary or norm, overstepping, transgression' (Arndt, Danker \& Bauer 2000:758). The word therefore implies the transgression of certain laws. This is why Paul could state: 'For the law brings about wrath, but where there is no law, neither is there violation' (Rm 4:15).

\section{Iniquity or lack of integrity}

According to the biblical testimony sin is also considered as iniquity or lack of integrity. The basic Hebrew word is (āwel), which implies a sense of 'injustice, unrighteousness'. In its verbal form (ִawal) means to 'act wrongfully' or unjustly (Brown et al. 2000:732). The equivalent Greek word is àvoría (anomia), which literally means 'lawlessness, violation of law, iniquity, sin' (Mounce 1993:78). The word also refers to the action of deviating from the right path, and can mean 'injustice, failure to fulfil the standard of righteousness, or lack of integrity' (Erickson 2013:523). Injustice is depicted as a sin, an iniquity which consists of denying people their rights, or treating them unfairly. This act is condemned strongly in the Scripture's rendition, particularly in Leviticus 19:15 where Moses warns the people of God, 'You shall do no injustice in judgement, you shall not be partial to the poor nor defer to the great, but you are to judge your neighbour fairly'.

\section{Rebellion}

In the Old Testament narratives sin is also described as rebellion. The most common word is עִ derives from the noun $\left(p e s h a^{\prime}\right)$ and has the sense of 'offense, rebellion, crime, legal offense, guilt, property offense, penalty' (VanGemeren 1997:706). Rebellion can be understood as an intentional breaking of the rules or norms, and covers different aspects. For example as VanGemeren indicates, rebellion entails offenses with respect to property and persons, the breaking of political alliances, but mostly it denotes rebellion against Yahweh. Various examples in the Scripture's testimony show how the people rebelled against God. That is why the prophet Isaiah had to inform the people of God: 'Sons I have reared and brought up, but they have revolted against me' (Is 1:2). The Hebrew word עשฺָׁ (pasha') finds its equivalent in the New Testament Greek $\alpha \dot{\pi} \varepsilon \dot{\theta} \theta \varepsilon 1 \alpha$

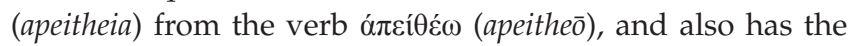
meaning of disobedience (Liddell \& Scott 2002:79). In this regard New Testament writers refer to the Gentiles as being disobedient (Heb 11:31). Erickson (2013:523-524) explains: because it is assumed that the law is written in their hearts, but they chose to disobey it. For that reason Paul consider them as without excuse (cf. Rm 1:18-19, 27-32).

\section{Treachery}

Sin is also characterised as being a treachery, of which the Hebrew word is $\left(m a^{\prime} a l\right)$. This term is 'closely related to the concept of sin as rebellion' (Erickson 2013:525). The term signifies 'unfaithfulness, faithless, undutiful, disloyal, infidelity, breach of trust, deceit, deception, fraud, malfeasance' as elucidated by VanGemeren (1997:1020). 
He makes it clear that the word in which the relationship of trust between peoples mutually, or between persons and God, has been breached. The vivid example in the Scripture's use of the term treachery can be found in Leviticus 26:40: 'If they will confess their iniquity and the iniquity of their forefathers, in their unfaithfulness which they committed against me, and also in their acting with hostility against me'.

Sin interpreted as treachery is also evident in the New Testament with the words $\pi \alpha \rho \alpha \tau i ́ \pi \tau \omega$ (paratiptō) and $\pi \alpha \rho \alpha \dot{\pi} \tau \omega \mu \alpha$ (paraptōma), which both mean 'to fall away' (Erickson 2013:525). This can be seen in Hebrews 6:6 when the author refers to a deliberate abandonment of faith after having once been enlightened and tasted the heavenly gifts. The point made is that there is an intentional drifting away and a refusal to repent because of the hardness of heart and that is why this form of sin is described as treachery.

After examining the various terms that emphasise the nature of $\sin$, this subsection focuses on the causes of $\sin$.

\section{Concepts that emphasise the causes}

The causes or factors leading people to commit sins can be identified as ignorance, error, and inattention. It is important to understand the causes of sin, seeing that such an insight inspires people to take the appropriate action when addressing and handling sin in relation to poverty.

\section{Ignorance}

To emphasise the cause of sin, the Old Testament testimony uses the verb פשָָ (shagag) and its synonym (shagah), which basically means 'to go astray, to commit sin or error, to err, to sin ignorantly or inadvertently' (Brown et al. 2000:993). The term (shagag) could also mean to make a mistake and not consider the consequences, to stagger, to do wrong (inadvertently, unintentionally), to lead astray, to mislead, or ignorantly commit sin (Koehler \& Baumgartner 1999:1413). Thus (shagah) designates an unintentional sin committed by an individual or by a community (VanGemeren 1997:44). The lucid picture of sinning through ignorance is presented in Numbers 15:22: 'But when you unwittingly fail and do not observe all these commandments, which the Lord has spoken to Moses'. In this context the entire community of Israel is held accountable for sins committed inadvertently or unconsciously (Walton, Matthew \& Chavalas 2000:152).

The corresponding term in the New Testament is ó $\gamma$ vora

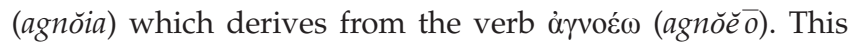
term has a broad spectrum of meaning: to be ignorant, fail to understand, for lack of capacity to comprehend, be unaware of one's wrongdoing, sin unintentionally or through ignorance (Mounce 1993:12). By implication it means to ignore someone, or something, through lack of enthusiasm. This word usually refers to an innocent form of ignorance. Apparently God did not reproach people for certain actions due to ignorance. This is evident in the narrative of Acts 17:30 where it reads:, 'Therefore having overlooked the times of ignorance, God is now declaring to men that all everywhere should repent'. However, the ignorance that is culpable or sinful is identified in Ephesians 4:18-19, which states that 'being darkened in their understanding, excluded from life of God, because of the ignorance that is in them, because of the hardness of their heart'. This form of ignorance is not considered as innocent because a voluntary refusal not to heed the Word of God causes people's understanding to be darkened. As mentioned in verse 19, it also leads to further ignorance and increased $\sin$. The sin of ignorance was therefore punishable. That is why the author of the book of Hebrews explains that once a year the high priest had to enter the Holy of Holies to offer the sacrifice for the sins he himself and all the people committed in ignorance (cf. Heb 9:7).

\section{Error}

The most common words used in the Old Testament to describe the cause of $\sin$ as error is $\left(t a^{\prime} a h\right)$. Its primary meaning is 'to err, to wander, to go astray in the sense of losing one's direction, both geographically and ethically' (Renn 2005:338). In a literal sense the word to describe the sheep that deviates from the flock, and in a figurative sense these words describe the human inclination to go astray and make mistakes (Erickson 2013:517). The picture of straying sheep is clearly shown in the renditions of Ezekiel 34:6 and Isaiah 53:6 that confirms: 'All of us like sheep have gone astray, each of us has turned to his own way; but the Lord has caused the iniquity of us all to fall on Him'.

The Greek word mostly used in the New Testament to designate sin as error is $\pi \lambda \alpha \nu \tilde{\omega} \mu \alpha$ (planōmai). The indicative mood is $\pi \lambda \alpha v \alpha$ ć (planaō) which basically means 'to cause to go astray from a specific way, to proceed without a sense of proper direction, be misled, wander about aimlessly' (Arndt et al. 2000:821). Emphasis is placed on being misled into sin as a result of deception, but this mistake can be avoided. It should be noted that according to biblical testimony, God neither created sin, nor caused people to commit sin. The phenomenon of sin is therefore considered as the result of free will leading to the depravity of humankind. Erickson (2013:518) underscores three possible sources that lead to error, which are elucidated below.

Firstly, evil spirits might be a source of error. In his book, God of the empty-handed, Christian (1999:150) asserts that evil forces can influence people in various situations with the goal 'to separate them from the love of God'. This is apparent in a statement such as: 'But the Spirit explicitly says that in later times some will fall away from faith, paying attention to deceitful spirits and doctrines of demons' (1 Tm 4:1). This passage describes the teachings of false teachers that lead people into errors which culminate into apostasy and indicate that the end times are underway (Beale \& Carson 2007:898). In his epistle to the Early Church, the Apostle John distinguishes the spirit of truth from that of error (1 Jn 4.6). It can be inferred that every human's action is either regulated by the spirit of error, or the Spirit of truth. The narrator of the 
book of Revelation explains how the devil was cast down to deceive the whole world ( $\mathrm{Rv} 12: 9)$. On the basis of these passages it can be concluded that in some instances members in a society may fall into error under the influence of evil forces that control their thoughts and actions.

Secondly, humans can deceive fellow human beings as the following biblical passages can attest. Ephesians 4:14 reads:

As a result, we are no longer to be children, tossed here and there by waves, and carried about by every wind of doctrine, by the trickery of men in deceitful scheming.

In the same vein 2 Timothy 3:13 states: 'But evil men and imposters will proceed, from bad to worse, deceiving and being deceived.'

Thirdly, people can also deceive themselves. This is made clear in 1 John 1:8: 'If we say we have no sin, we are deceiving ourselves, and the truth is not in us.' Self-deception takes place when people profess false innocence. God condemns such an attitude as stated in the following Scripture (Jr 2:35): 'You said I am innocent; surely his anger is turned away from me. Behold, I will enter into judgment with you because you say I have not sinned.'

It is worth mentioning that error, ${ }^{2}$ particularly those that give rise to poverty, can be avoided. This is why Lötter (2008:17) describes poverty as an avoidable situation. For that reason the Scripture's testimony encourages people not to give in to sin, by expressions such as: 'See to it that no one misleads you' (Mk 13:5), or, 'Do not be deceived' (Gl 6:7; 1 Cor 6:9; 1 Jn 3:7). However, in some instances God, according to the Bible, recognised innocent errors and attached no punishment to it (e.g. killing someone unintentionally). This was the main reason for the cities of refuge or asylum recorded in the Old Testament narratives (Nm 35:9-15; Jos 20). Nevertheless in most cases all errors were punishable and ignorance was not accepted as an excuse. Individuals had the moral obligation to get informed and take heed in order to avoid falling into punishable errors.

\section{Inattention}

The Scripture's testimony uses another word to describe the cause of sin as inattention. The Greek word $\pi \alpha \rho \alpha \kappa o \eta n ~(p a r a k o \bar{e})$ derives from the verb $\pi \alpha \rho \alpha \kappa o v \omega ~(p a r a k o u \bar{o}$ ), which has the meaning of 'refusal to listen and so be disobedient, unwillingness to hear; disobedience' (Arndt et al. 2000:766). In many New Testament passages the word $\pi \alpha \rho \alpha \kappa o \eta n$ is used mostly to denote disobedience due to inattention (Erickson 2013:519). This amounts to saying that someone is hearing the truth but does not pay attention to it. As a result such persons become increasingly insensitive to the truth until their hearts is hardened. The passage in Hebrews 2:2-3 clearly illuminates

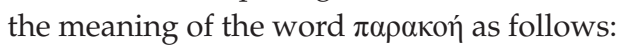

2.Sin is the transgression of God's commandment whereas error is the tendency in human beings to make mistakes, while a mistake is 'a misconception about the human beings to make mistakes, while a mistake is 'a misconception about the
meaning of something; a thing incorrectly done or thought; an error of judgement' meaning of something; a thing incorrectly
(Oxford English Dictionary 2016:1600).
For if the word spoken through angels proved unalterable, and every transgression and disobedience received a just recompense, how shall we escape if we neglect so great a salvation? After it was at the first spoken through, it was confirmed to us by those who heard.

The narrator underlines the fact that rejecting God's Word is a serious offense that has far-reaching consequences. Erickson (2013:519) rightly argues that the sin of inattention ( $\pi \alpha \rho \alpha \kappa \eta$ ) can be understood either as the failure to listen and pay attention to what God said, or as disobedience due to mishearing God's message.

It should be noted that according to the biblical testimony, sin can be individual or collective. In referring to individual sin, Erickson (2013:585) describes it as 'actions, thoughts, and dispositions that characterize individual human beings'. It is worth mentioning that collective sin is a neglected theme among Evangelicals because, as he (Erickson 2013:585) points out, the tendency is to pay more attention to individual sin, seeing that $\sin$ and personal salvation are considered primary. Social sin is, however, a reality in contemporary society. It is often referred to as social injustice. This form of sin can be identified in many wrongful acts by the government, political and economic structures, and in detrimental actions such as human rights violations, discrimination, racism or imperialism. Politics and political economy can function as structural forces leading to evil practices. The classical words of Gutiérrez (1973) explain this reality vividly:

Sin is evident in oppressive structures, in the exploitation of man by man, in the domination and slavery of people, races, and social classes. Sin appears, therefore, as the fundamental alienation, the root of a situation of injustice and exploitation. (p. 175)

This view is also confirmed by Rodney (2012:5) who argues that the current underdevelopment which most African and Asian countries are experiencing is the result of capitalism, imperialism and colonialist exploitation. In other words, according to Rodney the underdevelopment is the consequence of 'the exploitation of one country by another'. While this view is still debatable, it is obvious that the issue of collective sin cannot be ignored.

The foregoing analysis of various concepts employed in the Old and the New Testaments to designate sin portrays the different characteristics and the multifaceted nature of this phenomenon. The basic principle that can be inferred from the biblical descriptions of sin as analysed by Erickson (2013) is that:

Sin is any lack of conformity, active or passive, to the moral law of God. This may be a matter of act, of thought, or of inner disposition or state. (p. 528)

He also understands sin as 'an inner force, an inherent condition, and a controlling power'. From the Christian perspective the failure to observe the Word of God is clearly expressed in the different biblical terms for sin, such as missing the mark, ungodliness, transgression, rebellion, iniquity and treachery. The main idea these different terms 
convey is that sin opposes the will of God. It is the failure to conform to God's virtues for righteousness of loving him sincerely and loving others.

From the perspective above sin can be seen as synonymous with lovelessness. In other words, the opposite of love is sin. This violation flows from ignorance of God's will or the obstinate rejection of his Word, and results in evil ${ }^{3}$ or wickedness. As noted above injustice, for example is a sin and evil of not treating all people fairly. This state of affairs breaches the aforementioned relationships and is one of the causes of poverty in the African society. In this sense Leviticus 19:15 warns: 'You shall do no injustice in judgement you shall not be partial to the poor nor deter to the great, but you are to judge your neighbour fairly.' In Zachariah 7:10 the Lord commends his people to dispense true justice and practice kindness and compassion to their fellow Israelites, not to oppress the widow or the orphan, the stranger or the poor, and not to devise evil in their heart against one another. Gutiérrez (1973:300) rightly asserts that 'the ultimate cause of man's exploitation and alienation is selfishness'. He indicates that the latter is a scandalous condition of poverty. From a similar perspective Wyngaard (2013:244) describes poverty not only as a personal attitude but also the full attitude of people before God and the relationships of people with one another. In this sense it becomes clear how sin relates to poverty and injustice.

The following section will discuss the prevalence of these dysfunctional relations in the African context.

\section{The reality of poverty in Africa}

It is unquestionable that the majority of the population in Africa is materially poor. However, the continent itself is not poor, but is endowed with a richness of natural resources. The situation of poverty that is widespread in current African society has a prolonged history, from the global slave trade, through extended periods of colonialism and neo-colonialism, to dictatorship regimes and indigenous reigns of terror. In addition the Cold War ideologies and post-Cold War politics, lengthy armed conflicts and the growing HIV pandemic are all contributing factors to the deepening of poverty in Africa.

This state of affairs is confirmed by the World Bank's estimate that 'nearly half of the world's population lives in poverty' (Brill 2005:305). Given this concern, the international community undertook a global initiative at the historical Millennium Summit to take action against poverty. The summit took place at the United Nations' headquarters in September 2000. At the summit 198 heads of states and governments adopted the United Nation's Millennium Declaration in which they made a firm commitment to the first goal: 'to eradicate extreme poverty and hunger' by 2015 (Langford, Summer \& Yamin 2013:2). Although the programme for the Millennium Development Goals ${ }^{4}$ (MDGs) concerns all countries of the world, sub-Saharan nations in Africa are unquestionably affected the most by poverty.

3.In this context, evil or wickedness is viewed as a condition or a state that is the consequence of sin.

4.As the MDGs have come to an end in 2015, they have been replaced by Sustainable Development Goals (SDGs)
Prior to the United Nations' General Assembly in 2000, religious and spiritual leaders held the Millennium Peace Summit in August 2000, in the course of which they demonstrated their commitment to world peace and to combatting poverty (Love 2001:1). Furthermore in July 2003 the Southern Africa MDGs Forum was held in Johannesburg to reframe poverty-reduction strategies in Southern Africa (Gabriel 2003:1). The religious and the world's political leaders demonstrated general good will to end poverty.

Despite the fact that a World Bank's recent report 'shows a broad reduction in extreme poverty' (Langford et al. 2013:209), the reality is that a significant portion of the world population is still living in poverty. It is estimated that 90 million of the population in Africa lives in rural areas and depend only on agriculture for their survival and 'more than one billion people lack access to clean water, and 6 million children die from malnutrition every year before their sixth birth day' (Beasley 2009:vii). According to the United Nations' human development index of the 45 poorest countries in the world in 2011, 37 nations or $82.22 \%$ of them were African countries (Mbaku 2014:531).

Thus the question remains: Why does poverty still persist? On the other hand, countries worldwide dispose of more resources than in the past. Due to an unprecedented advance in technology, the world is experiencing increased agricultural production. Thus the means are there not only to eliminate abject poverty that has ravaged many lives thus far, but to prevent poverty from spreading as well. This suggests that the type of poverty the world is currently experiencing is not primarily due to natural disasters or war, but it may also in its core be a problem caused by humans and social relationships.

Unfortunately the Millennium Development Goal 1 (MDG) as stipulated in the United Nations Declaration aiming to eradicate extreme poverty and hunger by $2015,{ }^{5}$ evidently failed to provide a comprehensive explanation of world poverty (its cause, nature and remedy), and the moral responsibility linked to it. The problem was that the mentioned goal was presented as if poverty is a process that merely takes its course and no one bears any significant responsibility for the persistence of globally deep-set poverty.

The fact is that poverty is not an easy concept to define. There is not a single universally accepted definition of poverty. It is a broad concept and a multifaceted phenomenon representing many overlapping meanings. Yet Odekon (2006) formulates a workable definition, namely:

Poverty is commonly thought as a state of deprivation in which individuals lack sufficient food, housing, clothing, medical care, and other basic items to maintain a decent standard of living. (p. 1)

Poverty as a theme has been the subject of much study and discussion in the academic circles and among policy makers. Various theories have been formed in attempts to explain 5.The MDGs ended in 2015, and were replaced by Sustainable Development Goals (SDGs). 
poverty and its causes, for example the pathological explanation of poverty that attributes the cause of this condition to the poor themselves, whereas the structural explanation argues that poverty results from socio-economic structures (Alcock 2006:35). Nevertheless poverty remains a huge challenge within Africa and around the globe. With regard to the agenda of global poverty Stott (2006:165) mentions three main issues, namely the indebtedness of poor nations, trade and aid. Stott argues that the vast structural inequality due to a heavy debt burden, injustice in internal trade and lack of quality aid for the majority of the countries in the world particularly in Africa, are causes of perpetual global poverty. For example Greece failed to repay its debts (Adam 2011:6); Ethiopia is currently the world's largest beneficiary of aid, but economic evidence suggests that such a pattern of aid flows tends to strengthen macroeconomic instability (Gebregziabher 2014:1).

\section{Biblical perspective on poverty}

The Bible uses a variety of words to describe the poor. Alexander and Baker (2003:884), for example point out the most common terms for poor in the Pentateuch as the foundation of Scripture as a whole:

- $\quad ל \underline{\text { T }}$ (dal): refers to an individual from a lower class such as a peasant farmer. These classes experience economic affliction and suffering at a certain level, but they are not completely deprived (Lv 14:21).

- אֶבְיוֹן ('ebyôn'): designates the most desperate poor (Ex 23:6, 10:11; Is 32:6-7) who do not have the means for survival, and are in a dire situation of destitute.

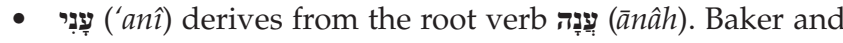

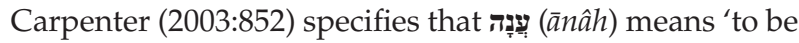
afflicted, to be poor, to be needy. It describes the poor and oppressed in a society'.

The Old Testament reveals multiple causes of poverty but the major causes are indicated as oppression, economic exploitation and injustice (Alexander \& Baker 2003:884). This corresponds with the mentioned main causes for the persisting cycle of poverty in Africa. To remedy the situation of poverty God provided for the Israelites detailed laws and regulations recorded in the Torah and designed to protect the poor and eradicate poverty in the land. For example the Torah insists that every Israelite should provide by interestfree loans for a fellow Israelite who became poor and needy (Lv 25:35-38). A debt-slave should not be kept in that condition perpetually, but should be released in the seventh year (Dt 15:12-18). The Lord commended that the land must lie fallow during the seventh year so that crops growing naturally without being sowed in a field during that time could be left for the poor (Ex 23:10-11). God also prohibited the oppression of a hired servant (Dt 24:14-15). It was forbidden to withhold the wages of a labourer, because if he cries out, the Lord will hear and the oppressor will be considered guilty of a sin (Dt 24:15). This is akin to what is taking place in some parts of African society today. For example in the $\mathrm{DRC}^{6}$ civil servants and workers in certain state companies can go for months without remuneration. The reason is not a lack of finances; very often it is because of the ill-intention of political leaders (Kakwata 2014:64).

Hoppe (2004:40) mentions three solutions the Torah offers to the widespread problem of poverty:

- Those who have some means have the duty to help those who are poor (Lv 5:7-13; 14:21-32).

- The Torah forbids the exploitation of people who are economically vulnerable.

- The Torah's laws prevent the emergence of a permanent debtor's class in Israel.

It seems that the Israelites did not follow the instructions God gave them on the eradication of poverty. This is probably part of the reason for continued widespread poverty in Israel. The Scripture testifies:

For the poor will never cease to be in the land; therefore I command you, saying, you shall freely open your hand to your brother, to your needy and poor in the land.

Hoppe (2004:121) echoes the same view: if Israel were to obey the Torah, poverty would not exist. It is the researcher's opinion that if the same principles could be applied presently in contemporary African society, abject poverty would be eradicated among the people.

The New Testament's Greek utilises the word $\pi \tau \omega \chi o ́ s$ (ptochos) to identify the poor. The word $\pi \tau \omega \chi$ ós occurs 34 times in the New Testament, and refers to an individual reduced to beggary, mendicant, poor, indigent (Perschbacher 1990:358). The New Testament testimony also uses the words

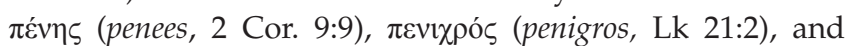
$\pi \tau \omega \chi \varepsilon i ́ \alpha$ (ptogeia, 2 Cor 8:2, 9; Rv. 2:9) to designate the poor and the destitute (Perschbacher 1990:319).

The Old Testament meaningfully portrays poverty as a sign of unfaithfulness to Yahweh or an evil caused by Israel's elite's class, while emphasising that God is the protector of the poor. In the New Testament which is the continuation, the promises as well as the culmination of the Old Testament's message, the poor receives different treatment. It portrays the poor as those who have an attitude of complete reliance upon God, who are destitute and marginalised in Jewish society, lack power and influence, and are vulnerable to exploitation by the class of elite's in Israel (Hoppe 2004:143). Hoppe indicates that the rich are condemned not because they are rich or wealth is detrimental, but because they do not observe the law by exploiting the poor. Proclaimed by Christ the advent of the kingdom of God brings the solution to the problem of poverty. That is why the proclamation of the coming of the kingdom of God was designated as good news to the poor. As Dempster, Klaus and Petersen (1991:17) specify, this does not only apply to the poor in spirit, but also the material poor in the literal sense of the word.

After discussing poverty according to the biblical perspective, the following section will deal with the relational understanding of poverty. 


\section{Relational understanding of poverty}

Myers (2007:86) views the nature of poverty as fundamentally relational. He asserts that 'poverty is the result of relationships that do not work, that are not just, that are not for life, that are not harmonious or enjoyable'. Lötter (2008:25) points out that poverty hurts people's familial and interpersonal relationships. These two views describe the multifaceted and the damaging effects of poverty. The areas impacted by the broken relationships are according to Myers (2007:87): 'within ourselves, with community, with those we call other, with our environment, and with God'. Christian (1999:118) also outlines four domains of poverty relationships or spheres of social practice, namely the state, civil society, corporate economy and the political community. Within these domains the dysfunctional relationships surface that give rise to and sustain the system of poverty.

In this regard Scripture provides various motives that elucidate the relational concept. Myers, quoted in Winter and Hawthorne (1999:579), infer from the Scripture's testimony that the first sin humans committed was relational in nature in the sense that after the Fall they 'were separated from an intimate relationship with God'. He rightly indicates that the Ten Commandments as listed in Exodus 20:1-17 and Deuteronomy 5:4-21 also inform social relationships. This is evident in Jesus' response to the teacher of the Law who tested him on the greatest commandment:

You shall love the Lord your God with all your heart, and with all your soul, and with all your mind. This is the great and foremost commandment. The second is like it, you shall love your neighbour as yourself. (Mt 22:37-40)

These two commandments which summarise the whole law and the prophets clearly reflect on social relationships. This concept is extremely important, seeing that it allows people to understand the world in terms of relationships and provides a new perception of poverty as relational.

Furthermore Myers (2007:87) emphasises an important point, namely that poverty find expression in 'relationships that lack shalom, that work against well-being, against life and life abundant'. This implies that poverty exists because of the lack of peaceful and right relationships. August (2010:37) explains further that peace (shalom) in question does not only mean the 'absence of strife, but also health, wholeness, prosperity, justice, harmony and general well-being'. This is the value of the kingdom of God as Paul points out: 'For the kingdom of God is not eating and drinking but righteousness and peace and joy in the Holy Spirit' (Rm 14:17). This indicates that people are called to live in peace, as Hebrews 12:14 advocates: 'Pursue peace with all and the sanctification without which no one will see the Lord'.

The absence of shalom gives rise to the above-mentioned deficiencies, namely dysfunctional relationships, social injustice, and disharmony of life which can lead to poverty. That is why Wyngaard (2013:215) explains that the poverty system is a result of relationship deficits within the economic system and which allows injustice to continue unchecked. He further argues that the relationship deficit therefore impedes healthy interaction needed for people to overcome poverty.

After examining the relational nature of poverty, and especially the relationship deficit leading to a system of poverty, the following subsection focuses on the concept of the image of God as foundation for healthy relationships.

\section{The concept of the image of God}

The concept of the image of God (דָ̣וּ - demuth; - tselem) mentioned in Genesis 1:26-28 is often considered as the central theme in biblical anthropology. It originates from the narrative of creation in Genesis 1:1-2:3, which proceeds from the creation of heavens and earth and reaches its climax in the creation of man: 'Then God said, let us make man in our image, according to our likeness ...' (v. 26). It is interesting to note that despite human beings falling into sin, both the Old and the New Testaments' writings (Gn 5:1-3; 9:6; 1 Cor 11:7; Ja 3:9) maintain that humans are created in the image and the likeness of God (Alexander \& Baker 2003:19). There is a consensus within mainstream Christian theology that 'sin does not destroy the image of God in human, but in fact it deforms and distorts it' (Vorster 2011:13). Dudley-Smith (1995) elucidates this notion:

Who am I? What is my 'self'? ... I am a Jekyll and Hyde, a mixedup kid, having both dignity, because I was created and have been re-created in the image of God, and depravity, because I still have a fallen and rebellious nature ... My true self is what I am by creation, which Christ came to redeem, and by calling. My false self is what I am by the fall, which Christ came to destroy. (p. 137)

There are different views on what God's image in humans implies. In his reflection of the image of God Hoekema (1994:67) introduces two concepts, namely 'mirror God and represent God'. He explains that these concepts imply that humans were created to reflect the life of God but also to represent God on earth. From this viewpoint it is clear that both concepts refer to humans' relationship with God. This is why Vorster (2011:4) asserts that the image of God in humans is 'a relational concept that indicates the nature of the human being's relationship with God'. Similarly Plantinga, Thomson and Lundberg (2010:189) emphasise the modelling function of representing the image of God by considering 'humanity as the royal stewards of the divine king of creation and its relational dynamic'. In their proposal of a representational, relational conception of the image of God they state that this image is revealed through the structure of its various relationships: humans with God, with other human beings and with nature.

In the light of this latter perspective Hoekema (1994:75) develops a theme of 'man in his threefold relationship' based on Genesis 1:26-28. He argues that God is relational and operates in a threefold relationship, Father, Son and Holy Spirit. This indicates God's desire to be in relationship with the world he created. For that reason God also endowed 
humans with the capacity to enter into relationships. This implies that human beings were not made to be lonely, but to live in relationship with God, with others and with their community, as well as in harmony with the environment. He (Hoekema 1994:75) also points out that humans' relationship with God is the most important in the sense that it controls the two other relationships. This emphasis on the essence of humans' relationships with God and their community, corresponds with Myers' (2007:86) depiction of the nature of poverty as fundamentally relational, providing a framework to understand the relationship between sin and poverty.

\section{The relational nature of the image of God}

Plantinga et al. (2010:194) stress the fact that God did not create the world because he was in need of doing it; he did it out of love and desire to be in relationship with the creation, as mentioned previously. They also indicate that the type of relationship God conducts with humanity is founded in love and has two objectives: to reveal the divine identity and will to humanity and to endow humanity with the ability to respond freely to God's love. This shows a sense of freedom and responsibility by which humankind benefits as an integral part of its calling in order to reflect the image and character of God in the multiple relationships with God, others and nature.

The central element that can be discerned in the divine relationship with humanity as identified by Plantinga et al. (2010:190) is divine grace. This undeserved favour grants human beings dignity and value. As noted above humanity is considered as God's representative on earth and called to care for God's creation. Thus to fulfil their role properly humans must maintain a sound relationship with God. This requires faithfulness and obedience to God (Plantinga et al. 2010:190). The biblical testimony refers to the relationship between humans and God as the covenant. Human beings are called to live in a covenantal relationship with God. God takes the first step in establishing this covenant of relationship with his people. This covenant comprises three parts: I will be your God (expression of God's determination); you will be my people; and I will dwell among you (Gn 17:7; Ex 6:7; 29:46). God's covenant is promised to all mankind. It finds its origin in Abraham (Gn 12:2-3) and its fulfilment in Jesus Christ (Gl 3:29). Thus God's image in humanity gives people the ability to be in communion with God. Ipgrave and Marshall (2011:13) specify that the covenant is a provision of grace for a new relationship God offered to his people who were banished from his presence such as stipulated in 1 Peter 2:9-10:

But you are a chosen race a royal priesthood, a holy nation, a people for God's own possession, that you may proclaim the excellences of Him who has called you out of darkness into marvellous light; for once you were not a people, but now you are the people of God; you had not received mercy, but now you have received mercy.

To illustrate the relational nature of the image of God, König in his article, 'The broken image of God' (in De Gruchy \&
Villa-Vicencio 1994:102-103) discusses the theme: 'We are relationship beings who only come into our own in relationships of love'. He stresses the representative connection, namely as God is love, a human being in his nature must also reflect love. König states that the relationships of human beings are characterised by love, and love is about 'commitment and caring'. He develops two concepts, viz. 'covenant partner and image of God' to explain how human beings relate to God, to others and to the environment. From this explication can be concluded that human beings are created for fellowship with God and with others, and to live in harmony with creation.

\section{The vocational nature of the image of God}

It should be noted that the image of God in human beings is not only viewed as relational in nature but is also understood as vocational, which is a gift from God and is revealed in the covenant relationship between God and human beings. As mentioned above the image of God in humans is not destroyed because of the fall but in fact it is distorted, and as Sands (2010:38) asserts it remains the basis of human dignity (Gn 9:6; Ja 3:9). It is clear that human dignity emanates from God and it is a calling; it can be soiled but not lost (Sands 2010:38). Thus every human being whether poor or non-poor has value before God because he is created in God's image and God endowed him with dignity as Genesis 9:6 illustrates in the following terms: 'whoever sheds man's blood, by man his blood shall be shed, for in the image of God He made man'. This shows that each human being must 'be treated as equal regardless of his race, gender, tribe or social position' (Ipgrave \& Marshall 2011:10).

It is clear that the vocational dimension of the image of God in human beings finds its clear expression in the redemptive work of Jesus on the cross. It also reveals the identity and humanity's created purpose through the loving covenantal relationship between God and humanity. Thus the way we treat others should not be based on personal feelings, but rather it should be informed by the command to love God and others. Likewise Myers (2007:115-116) argues that the poor suffer from marred identity and degraded vocation. He further asserts that when the poor are treated as equals, this can help them recover their true identity and vocation that is embodied in the image of God in humans which is a gift from God that contributes to the wellbeing of the poor themselves and to their community.

\section{Social implications of the image of God}

The concept that human beings were created in the image of God has clear social implications. Plantinga et al. (2010:191) point out that the image of God in humans is not only about a faithful relationship with God, but also encompasses the relationship with fellow human beings - in brief it involves the whole social order. This fact is well elucidated in Genesis 1:27 according to which 'God created man in his own image, in the image of God He created him; male and female $\mathrm{He}$ created them'. This passage reveals the relational nature of 
the image of God according to the biblical view, and how that image is reflected in all of human's relationships.

As noted previously God did not create human beings to live in isolation but rather to enjoy fellowship with others. From this perspective Grenz (2000:207) notes that God made humans to be in relationship with other human beings and to be part of the family of God. He continues to stress that God's intention is that humans live in fellowship with others and be part of the community. But sin is the exact opposite as König in De Gruchy and Villa-Vicencio (1994:109) emphasises: sin is 'to live either in wrong or in broken relationships'. From this can be concluded that it is necessary for humans to foster sound relationships within their various circles of interaction: family, community and even in the nation at large. In doing so humans reflect the image of God in them, and every person discover their identity as childen of God individually. Plantinga et al. (2010:191) rightly argue that to live according to God's image, could also mean to stand in effective relationships (with God and other humans). This condition is measured by humans' love of God and therefore also for their neighbours, as Jesus emphasised in Matthew 22:37: 'The second [commandment] is like it, you shall love your neighbour as yourself'.

The biblical testimony underlines the importance of community life. 1 John 4:20 in particular stipulates: 'If someone says, I love God and hates his brother, he is a liar; for the one who does not love his brother who he has seen, cannot love God whom he has not seen.' Since love is the driving force in people's relationships with God and other humans, it follows that the absence of love creates sin that disrupts the relationships in its various dimensions. In their study of the harmful effect of sin on the aforementioned relationships, Plantinga et al. (2010:194) point out that the 'ignorance of God's will, the unbalanced concern for the desire of the self', harm and destroy others. Erickson (2013:564) makes the inference that $\sin$ is therefore the inability to love. In other words $\sin$ is the opposite of love. As Grenz (2000:207) indicates, sin leads to the destruction of the community at the level of the various relationships.

Erickson (2013:554) identifies contributing factors such as a lack of concern for others and exploitation of fellow humans that affect people's relationships with others, and as a result destroys the community. The loss of community can be seen in human rights violations, as well as in oppressive, exploitative and injustice systems - which all instigate and perpetuate the cycle of poverty. Myers (2007:87) rightly argues that poverty systems find their expression in broken relationships. He understands poverty as a result of fragmented, dysfunctional or oppressive relationships, which create and sustain a cycle of poverty. Gutiérrez (1973:175) also confirms this view and explains that sinfulness should be seen as a social and historical reality, a relationship where brotherhood and love fail, a breaking off of a relationship with God and others, and also 'an interior, personal fracture'. He focuses on the rise of oppressive structures in which humans exploit their fellow human beings, for instance slavery which brutalised, dominated, damaged and humiliated many people, particularly in Africa; also racism and social segregation. According to him these structures find their origin in human sinfulness. At this point the relationship between sinful behaviour and poverty becomes evident.

It is obvious that sin should be considered universal and manifests itself on a personal as well as societal level. The sins committed against God and other people provide a sound point of departure for understanding how the masses around the globe, and particularly in Africa, have sunk in abject poverty and misery. That is why Myers (2007:86) fairly emphasises that poverty is essentially relational. Dysfunctional relationships between people and between people and God are seen as the root cause of poverty. This process is well elucidated by three parables.

The first parable is found in Matthew 25:31-46 where Jesus announced the judgement with his return. He will reward those who help the needy and the destitute, but people who refuse to assist others who are in desperate need and trapped in abject poverty will be thrown into the eternal fire with the reproach: 'for I was hungry you gave Me nothing to eat; I was thirsty you gave Me nothing to drink'. The second parable is about the rich man and Lazarus. The problem with the rich man is that he did not attempt to help Lazarus who was hungry. He did not care about him in this life. Therefore the rich man's destiny was the eternal fire (Lk 16:19-30). The third parable narrates the Good Samaritan. In this case the Samaritan did accept responsibility for the man who was beaten almost to death by gangsters, whereas the adherents of formal religion turned away (Lk 10:29-30).

These parables explicitly show the importance of healthy relationships as the key to alleviate poverty. Where these relationships lack, it gives rise to and sustain poverty in society. There are two principles that can be derived from the Scripture which can help maintain good relationships, namely love for God and love for the neighbour (Dt 6:5; Lk 10:25-37). Wyngaard (2013:236) analyses the entire chapter of Leviticus 19 to find significant relational attitudes necessary for human daily life in order to address the problem of poverty. This entails a wide range of right relationships: with God (v. 2), parents (v. 3), the poor (v. 9-10, 15), neighbours (v. 11, 13-17), the disabled (v. 14), children (v. 29), the elderly (v. 32), and with strangers (v. 34). This implies a lifestyle of fostering sound relationships.

Thus it confirms Myers' (2007:118) thesis that the nature of poverty is essentially 'a relational framework that links everyone to God, to themselves, to their community, to those who are other and to the environment Sin is the harmful element that affects the relationships and thereby influences the cycle of poverty. As remedy to this deficiency Myers advocates the restoration of what he calls 'one's central relationship with the triune God, the God of the Bible' through faith in Jesus Christ. Myers points out the significant fact that human life and relationships are inseparable. Thus restoring the relationship with God implies placing God at 
the centre of one's life as the key factor for transformation and change, which spreads outwards to include one's fellow humans within the context of their daily lives.

\section{Conclusion}

The stated purpose of this article was to investigate the link between sin and poverty from a biblical point of departure. Sin is a crucial concept in Christian theology as well as in the context of poverty relationships. It is a subject the biblical testimony addresses in a specific way by providing underlying diagnoses for the causes, the character, and the consequences of sin. Sin also entails a multifaceted phenomenon which can be traced to the root cause of failing to comply with God's prescriptions in his Word. This is due to factors such as ignorance of the Scripture, errors, and inattention to God's law - actions that hold extremely negative and destructive consequences.

Poverty refers to a situation where an individual or a community experience economic affliction and suffering, lack of means for survival, or a condition of dire needs. It is the author's opinion that such a situation is mainly the result of oppression, economic exploitation and injustice by human beings toward others. These destructive actions flow from the consequences of ignorance towards God's will or the obstinate rejection of his Word. Such conduct portrays dysfunctional relationships between humans and between persons and God, which also reflects the absence of love. At this stage the link between human sinfulness and poverty can be pointed out clearly. The restoration of broken relationships with God, with the community, and with others through faith in Christ is the key factor that can help break the cycle of poverty.

\section{Acknowledgements Competing interests}

The author declares that he has no financial or personal relationship(s) that may have inappropriately influenced him in writing this article.

\section{References}

Adam, C., 2011, 'Greece's debt crisis: The price of cheap loans', Policy, viewed 6 August 2015, from http://nwulib.nwu.ac.za/login?url=http://search.ebscohost.com/ login. aspx?direct=tru\&db=aph\&AN=66835830

Alcock, P., 2006, Understanding poverty, 2nd edn., Macmillan, London.

Alexander, T.D. \& Baker, D.W. (eds.), 2003, Dictionary of the Old Testament: Pentateuch, InterVarsity, Downers Grove, IL.

Arndt, W.G., Danker, F.W. \& Bauer, W., 2000, A Greek-English lexicon of the New Testament and other early Christian literature, 3rd edn., University of Chicago Press, Chicago, IL.

August, K.T., 2010, Equipping the saints: God's measure for development, The Print Man, Cape Town.

Baker, W. \& Carpenter, E., 2003, The complete word study dictionary: Old Testament, AMG, Chattanooga, TN

Beale, G.K. \& Carson, D.A., 2007, Commentary on the New Testament use of the Old Testament, Baker Academic, Grand Rapids, MI.

Beasley, T.W., 2009, Poverty in Africa, Nova Science Publishers, New York.
Bowden, J., 2005, Encyclopedia of Christianity, Oxford University Press, New York. Brill, E., 2005, The encyclopedia of Christianity, vol. 4, Eerdmans, Grand Rapids, MI. Brown, F.F., Gesenius, W., Driver, S.R. \& Briggs, C.A., 2000, The Brown-Driver-Briggs Hebrew and English lexicon, Hendrickson, Peabody, MA.

Chan, S., 2001, Man and sin: A study guide, Global University, Springfield, MO.

Christian, J., 1999, God of the empty-handed: Poverty, power and the kingdom of God, MARC, Monrovia, CA.

De Gruchy, J.W. \& Villa-Vicencio, C., 1994, Doing theology in context: South African perspectives, Orbis, Maryknoll, NY.

Dempster, M.A., Klaus, B.D. \& Petersen, D. (eds.), 1991, Called and empowered: Global mission in Pentecostal perspective, Hendrickson, Peabody, MA.

Dudley-Smith, T., 1995, Authentic Christianity: From the writings of John Stott InterVarsity, Leicester.

Erickson, M.J., 2013, Christian theology, 3rd edn., Baker Academic, Grand Rapids, MI.

Gabriel, N., 2003, 'The millennium development goals: Towards a civil society perspective on reframing poverty reduction strategies in Southern Africa', viewed 27 May 2015, from http://www.ipc-undp.org/publications/mdg/SouthAfrica_ MDG Forum-Jul03.pdf

Gebregziabher, F., 2014, 'The long-run macroeconomic effects of aid and disaggregated aid in Ethiopia', viewed 6 August 2015, from http://onlinelibrary.wiley.com. nwulib.nwu.ac.za/journal/10.1002/\%28ISSN\%291099-1328/issues

Grenz, S.J., 2000, Theology for the community of God, Eerdmans, Grand Rapids, MI.

Gutiérrez, G., 1973, A theology of liberation: History, politics and salvation, SCM, London.

Hoekema, A.A., 1994, Created in God's image, Eerdmans, Grand Rapids, MI.

Hoppe, L.J., 2004, There shall be no poor among you: Poverty in the Bible, Abingdon, Nashville, TN.

Ipgrave, M. \& Marshall, D. (eds.), 2011, Humanity: Texts and contents - Christian and Muslim perspectives, Georgetown University Press, Washington, DC.

Kakwata, F., 2014, 'The Pentecostal church in the Congo/30ème communauté: Engaging in poverty eradication', PhD thesis, Department of Practical Theology, University of Stellenbosch.

Koehler, L. \& Baumgartner, W., 1999, The Hebrew and Aramaic lexicon of the Old Testament, Brill, Leiden.

Langford, M., Summer, A. \& Yamin, A.E., 2013, The millennium development goals and human rights: Past, present and future, Cambridge University Press, Cambridge.

Liddell, G.H. \& Scott, R., 2002, Greek-English lexicon, Clarendon, Oxford.

Lötter, H., 2008, When I needed a neigbour were you there? Christians and the challenge of poverty, Lux Verbi BM., Wellington.

Love, J., 2001, 'Religion in politics: Reflections on the UN's Millennium World Peace Summit of religious and spiritual leaders', viewed 27 May 2015, from http:// onlinelibrary.wile.com/doi/10.1111/1528-3577.00041/epdf

Mbaku, J.M., 2014, 'The rule of law and poverty eradication in Africa', viewed 12 May 2016, from http://eds.b.ebscohost.com.nwulib.nwu.ac.za/ehost/pdfviewer/ pdfviewer?vid=c6c7b39b-b3d4-4e8d-a2ce-012066ae

Mounce, W.D., 1993, The analytical lexicon to the Greek New Testament, Zondervan, Grand Rapids, MI.

Myers, B.L., 2007, Walking with the poor: Principle and practices of transformation development, Orbis, Maryknoll, NY.

Odekon, M., 2006, Encyclopedia of world poverty, Sage, Thousand Oaks, CA.

Oxford English Dictionary, 2016, viewed 26 February 2016, from http://www.oed com.nwulib.nwu.ac.za/search?search Type $=$ dictionary $\& q=$ mistake $\&$ searchBtn=Search

Perschbacher, W., 1990, The New analytical Greek lexicon, Hendrickson, Peabody, MA

Plantinga, R.J., Thompson, T.R. \& Lundberg, M.D., 2010, An introduction to Christian theology, Cambridge University Press, Cambridge.

Renn, S.D., 2005, Expository dictionary of Bible words: Word studies for key English Bible words based on the Hebrew and Greek texts, Hendrickson, Peabody, MA.

Rodney, W., 2012, How Europe underdeveloped Africa, Black Classic Press, New York.

Sands, P., 2010, 'The imago Dei as vocation', viewed 17 May 2016, from http:// biblicalstudies.2010-1_028.pdf

Stott, J., 2006, Issues facing Christian today, 4th edn., Zondervan, Grand Rapids, MI.

VanGemeren, W.A., 1997, New international dictionary of Old Testament theology and exegesis, Zondervan, Grand Rapids, MI.

Vorster, N., 2011, Created in the image of God: Understanding God's relationship with humanity, Pickwick, Eugene, OR.

Walton, J.H., Matthew, V.H. \& Chavalas, M.W., 2000, The IVP Bible background commentary, InterVarsity, Downers Grove, IL.

Winter, R.D. \& Hawthorne, S.C., 1999, Perspectives on the world Christian movement: A reader, William Carey Library, Pasadena, CA.

Wyngaard, J.G., 2013, 'In search of root causes of poverty testing a theological perspective in development dialogues', PhD thesis, Department of Practical Theology, University of Stellenbosch. 